\title{
Foreign Direct Investment Performance:
}

\section{A Stochastic Frontier Analysis of Location and Variance Determinants}

\author{
Marie M Stack ${ }^{\mathrm{a} *}$, Geetha Ravishankar ${ }^{\mathrm{a}}$ and Eric Pentecost ${ }^{\mathrm{b}}$

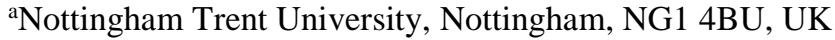

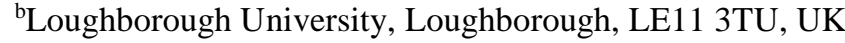

The opening up process of the eastern European countries was marked by greater integration of foreign direct investment (FDI) with their western neigbouring countries. Using the single step maximum likelihood (ML) approach to stochastic frontier analysis (SFA), the location and variance determinants of FDI are estimated using the knowledge capital (KK) model framework. The findings, based on a panel of bilateral FDI stocks from 10 western to 10 eastern European countries over the 1996 to 2007 period, suggest FDI is determined by both horizontal and vertical motives while the process of liberalisation and infrastructural developments significantly reduce the variance of FDI. In using a stochastic frontier specification of the KK model, the efficiency of FDI performance is identified relative to maximum levels. The bilateral efficiency scores suggest a mixed performance, indicating scope to improve the efficiency of FDI.

JEL Classification: C33, F21, P27

Keywords: Knowledge Capital model, stochastic frontier analysis, FDI performance

*Corresponding author. Email: Marie.Stack@ntu.ac.uk 


\section{Introduction}

A substantial literature is dedicated to analysing the location determinants of FDI into the eastern European countries with most studies focusing on the FDI effects of host country policy determinants using a gravity model framework. For example, Carstensen and Toubal (2004) highlight the importance of the privatisation process and country risk; others emphasise the effect of announcements regarding the accession process (Bevan and Estrin 2004; Clausing and Dorobantu 2005); labour costs are of concern for Bellak et al. (2008); while Bellak et al. (2009) consider the effects of infrastructure endowments and taxes. Much less attention, however, has been devoted to analysing the performance of FDI, partly explained by the limitations of FDI data (missing, zero and negative values $)^{1}$ and partly because regional specialisation yields very uneven patterns of bilateral FDI.

Some exceptions exist: Rojec and Damijan (2008) consider the potential for FDI relocations from 'old' to 'new' member countries of the European Union (EU) on the basis of a country's inward FDI relative to the size of its economy; Demekas et al. (2007) analyse the deviation from predicted levels given optimal policies; while Egger (2010) draws on the trade literature to compare the discrepancy between 'normal' and 'actual' activity. These studies, however, inherently assume optimal performance levels. In

\footnotetext{
${ }^{1}$ Investment projects often involve a large initial outlay of capital - in purchasing a factory unit, for example - and may incur smaller expenditures thereafter, implying FDI data can be 'lumpy' in its range between large values one year and low or zero values the next. Missing values suggest no FDI takes place while disinvestment (negative values) can occur if a company divests its subsidiary of assets for more productive use elsewhere. Note that FDI stock data help iron out the irregular patterns of FDI flows.
} 
reality, benchmarking FDI performance in the eastern European countries against optimal performance levels of western countries is questionable. Dropping the assumption of optimal (fully efficient) performance levels, the aim of this study is to use stochastic frontier analysis (SFA) within the knowledge capital (KK) model framework (Carr et al. 2001; Blonigen et al. 2003) to examine bilateral FDI performance for a panel of FDI stocks between 10 western European countries (Austria, Denmark, Finland, France, Germany, Italy, the Netherlands, Norway, Switzerland and the United Kingdom) and 10 eastern European countries (Bulgaria, the Czech Republic, Estonia, Hungary, Latvia, Lithuania, Poland, Romania, Slovakia and Slovenia) over the 1996 to 2007 period. In order to assess FDI performance, the advantages of using the Reifschneider and Stevenson (1991) approach to SFA are four fold. First, FDI performance can be benchmarked relative to a maximum level feasible for the countries of interest. If two countries are fully efficient, they will operate on the boundary of the frontier and will realise their maximum FDI performance otherwise deviations of actual FDI from frontier estimates indicate inefficient levels of FDI, implying scope for improved FDI performance. Second, the parameters for both the stochastic frontier and the inefficiency functions can be estimated simultaneously, the latter allowing for factors that affect the variance of inefficiency. Consequently, the position of the frontier is identified by the location determinants of FDI, which are specified in terms of the country characteristics relating to the types of firms in the KK model, while inefficiency is determined by the KK policy factors and additional FDI related policies specific to the eastern European countries. 
Third and in contrast to Armstrong's (2011) SFA analysis of China's performance of investment overseas, the SFA approach adopted in this paper inherently allows for a scaling property whereby changes in policy factors that affect FDI efficiency alter the scale, but not the shape of the inefficiency distribution. Following Alvarez et al. (2006), a base level of inefficiency exists because of innate limiting factors - typically interpreted as economic distance (Kalirajan 2008). Given these limiting factors, the ability to attain maximal FDI performance will then depend on a set of mitigating policy factors. Last, in dealing with the potential problem of heteroscedasticity, the functional form assumptions of this approach are more suitable to assessing FDI performance. In combination, the Reifschneider and Stevenson (1991) frontier specification of the KK model represents a novel approach to assessing FDI performance for the eastern European countries.

The results for the location determinants of FDI in the KK model suggest foreign investors pursue strategies relating to both horizontal FDI (GDP, the skilled labour difference and the interaction term between the product of the differences in economic size and skilled labour endowments) and vertical FDI (geographic distance and the interaction term between the host country trade costs and the square of skilled labour differences). The inefficiency determinants of FDI suggest physical infrastructure and the process of liberalisation in the eastern European countries are most important in reducing the variance of FDI inefficiency.

The bilateral efficiency scores suggest the reforming countries achieve better FDI performance. At the top end of the rankings, Hungary, Estonia and Poland are the best performing countries while Lithuania, Slovakia and Slovenia are among the three poorest performing countries in terms of FDI. Attaining a score of around 50, a rather 
heterogeneous group of countries are wedged between the best and worst performers (Bulgaria, the Czech Republic, Latvia and Romania).

This paper is structured as follows. Section II presents the traditional specification for the KK model of FDI location determinants. Extending the KK model to allow for technical inefficiency, the stochastic frontier specification of FDI location and variance of inefficiency determinants is also described in this section. Section III presents the data definitions and sources. The results in Section IV are split between the parameter estimates for the KK model and the efficiency scores of bilateral FDI performance. Section V concludes.

\section{Model Specification and Estimation}

The knowledge capital model

According to the KK model predictions, different country characteristics favour different firm types (Carr et al. 2001). Vertically integrated MNEs tend to split their production activities across different countries to avail of lower cost inputs in the production process. Take, for example, the production of final goods in a labour intensive industry such as textiles; the availability of a low cost, relatively unskilled labour force becomes potentially important. In this case, the firm will locate its headquarter (HQ) activities in the skilled labour abundant country and will locate its production facilities in the unskilled labour abundant country. Costs unrelated to production inputs can also influence the firm's decision to invest; negligible transaction and transport costs can stimulate foreign investment seeking cost efficiencies. In other words, vertical MNEs 
dominate other firm types if trade costs are low and countries differ in their factor endowments.

In contrast, horizontally integrated firms go abroad to increase their market share by gaining access to large foreign markets which provide opportunities for both scale and scope economies in the production of tradable goods. Consequently, these MNEs organise similar production activities across similar countries. High tariffs create an additional incentive for horizontally integrated MNEs. Known as the 'tariff-jumping' motive, firms circumvent protectionist measures by producing goods locally as an alternative to exporting into that market. High trade costs will have a similarly incentivising effect. Therefore, horizontal MNEs dominate production when trade costs are moderate to high and countries are similar in size and in relative factor endowments. ${ }^{2}$ In short, both vertically integrated and horizontally integrated MNEs can arise in the hybrid model.

Of course, the ability of the KK model variables to pick up the effects on HFDI and VFDI is conditional on the countries in the sample. Carr et al. (2001) explain the predominance of horizontally integrated MNEs using affiliate sales data for the US and 36 mainly high income countries. Both types of FDI are likely to prevail between the western and the eastern European countries.

Adapting the KK model of affiliate sales (Carr et al. 2001) to FDI, the different country characteristics can be aligned with vertical FDI (VFDI) and horizontal FDI

\footnotetext{
${ }^{2}$ National firms can also arise if the country is large and is skilled labour abundant; if trade costs are low and countries are similar in size and in relative endowments; or if there are high investment barriers in the foreign country.
} 
(HFDI) respectively in much the same way that country characteristics have been aligned with the disaggregated firm types of vertically and horizontally integrated MNEs in the hybrid model. Therefore, the specification for the location determinants of FDI (Blonigen et al. 2003) is:

$$
\begin{aligned}
& F D I_{i j}^{t}=\beta_{0}+\beta_{1} G D P_{i}^{t}+\beta_{2} G D P_{j}^{t}+\beta_{3} D G D P S Q_{i j}^{t}+\beta_{4} D I S T_{i j} \\
& +\beta_{5} \operatorname{TRADECOST}_{i}^{t}+\beta_{6} \operatorname{TRADECOST}_{j}^{t}+\beta_{7} \operatorname{INVCOST}_{j}^{t} \\
& +\beta_{8} D S K I L L_{i j}^{t}+\beta_{9}\left(D G D P_{i j}^{t} \times D S K I L L_{i j}^{t}\right) \\
& +\beta_{10}\left(T R A D E C O S T_{j}^{t} \times D S K I L L S Q_{i j}^{t}\right)+\varepsilon_{i j}^{t}
\end{aligned}
$$

where $F D I_{i j}^{t}$ refers to outward bilateral FDI stocks between 10 western and 10 eastern European countries over the 1996 to 2007 period; $G D P_{i}^{t}$ and $G D P_{j}^{t}$, represent national income for both countries and the difference of GDP squared, $D G D P S Q_{i j}^{t}=\left(\ln G D P_{i}^{t}-\ln G D P_{j}^{t}\right)^{2}$, denotes country size similarity. As large countries engage in more HFDI, the GDP coefficients should be positively signed in the KK model. HFDI is also prominent among similarly large countries, implying the difference of GDP squared, $D G D P S Q_{i j}^{t}$, should be negatively signed, otherwise a positively signed coefficient suggests countries differ in size.

Distance between the two countries' capital cities, $D I S T_{i j}$, represents an element of trade and investment costs. As an element of trade costs, its coefficient sign is ambiguous, depending on the prevailing type of FDI. Whereas a positive effect points to the presence of HFDI aligned with the tariff jumping motive of FDI, a negative effect suggests trade costs have a deterring effect on VFDI. In practice, however, a negative effect is commonly found in the empirical literature, perhaps reflecting the shortcomings of distance as a measure of trade costs. As an element of investment costs, restrictions on 
FDI discourage all foreign investors, implying an expected negative effect irrespective of the FDI type.

Carr et al. (2001) include measures of the perceived costs associated with trading and investing abroad. As high trade costs stimulate HFDI in the destination market, the index coefficient of trade protectionism for the host country, TRADECOST $T_{j}^{t}$, is expected to be positively signed. In contrast, high trade costs reduce the VFDI incentive to locate plants abroad for the shipment of goods back to the home market, implying a negatively signed coefficient for the home country, TRADECOST $T_{i}^{t}$. Investment restrictions, $I N V C O S T_{j}^{t}$, including constraints on acquiring control in a company, labour controls on hiring and firing as well as barriers to accessing capital markets will negatively affect FDI, regardless of the type.

As a proxy for relative factor endowments, skilled labour differences, $\operatorname{DSKILL}_{i j}^{t}=\left(\ln S K I L L_{i}^{t}-\ln S K I L L_{j}^{t}\right)$, can be ambiguously signed, but will often be positively signed because a firm's headquarters tend to be located in the skilled labour abundant country. Two interaction terms capture the interplay between skilled labour endowments, GDP and trade costs. The first interaction term, $\left(D G D P_{i j}^{t} \times D S K I L L_{i j}^{t}\right)$, between differences in GDP, $D G D P_{i j}^{t}=\left(\ln G D P_{i}^{t}-\ln G D P_{j}^{t}\right)$, and skilled labour, $D S K I L L_{i j}^{t}=\left(\ln S K I L L_{i}^{t}-\ln S K I L L_{j}^{t}\right)$, will be negatively signed in favour of VFDI and the geographic separation of a firm's headquarters from its production facilities. According to the simulations of Carr et al. (2001), affiliate production is highest when the home country is relatively small and is highly skilled labour abundant. Therefore, the 
firm's headquarters will be located in the home country, which is abundant in skilled labour and the firm's production facilities will be located in the foreign country, which is large enough to support production at a lower cost.

The second interaction term, $\left(T R A D E C O S T_{j}^{t} \times D S K I L L S Q_{i j}^{t}\right)$, between trade costs in the host country and the square of the skilled labour difference, $D S K I L L S Q_{i j}^{t}=\left(\ln S K I L L_{i}^{t}-\ln S K I L L_{j}^{t}\right)^{2}$, will be negatively signed because VFDI weakens the positive association between horizontal MNEs and high trade costs. Empirical support for this hypothesis, however, is weak as its predicted effect depends on the assumptions made in relation to skilled labour endowments. If, on one hand, the coefficient for DSKILLSQ is assumed to be positively signed because a firm's headquarters tends to be located in the skilled labour abundant country regardless of the FDI type, then a positive coefficient for the interaction term indicates the presence of HFDI (high trade costs go hand in hand with HFDI) and a negative coefficient is a signal of VFDI (high trade costs reduce VFDI). If, on the other hand, the coefficient for DSKILLSQ is assumed to be negatively signed because countries are similar in skilled labour endowments, then the overall effect of the interaction term will be reversed in sign for the FDI types. The error term is denoted as $\varepsilon_{i j}^{t}$. A summary of the KK model variables is provided in Table 1.

The knowledge capital model estimated using stochastic frontier analysis 
To assess FDI performance, the KK model is estimated using SFA to gauge actual performance between the western and the eastern European countries against a benchmark frontier function. In a production context, SFA can determine the maximum output that can be produced by optimising agents who transform inputs into outputs. If the production process is fully efficient, actual output will coincide with the boundary level of output on the production frontier. If, however, the production process is technically inefficient, actual output falls short of frontier levels, implying scope for improved production performance. Typically used in the analysis of firm performance in the banking sector, ${ }^{3}$ the SFA framework can be used to examine foreign investor performance. For a given country pair, actual bilateral FDI performance can be compared with the maximum possible level of FDI defined by a frontier, with any difference attributable to (technical) inefficiency.

Proposed by Aigner et al. (1977) and Meeusen and van den Broeck (1977), frontier functions and efficiency effects can be estimated using SFA. In analysing the role of exogenous influences on firm performance early studies adopted a two stage approach, but the second stage estimation is inconsistent with the assumption of independently and identically distributed inefficiency of the first stage (Battese and Coelli 1995; Kumbhakar and Lovell 2000). To overcome this shortcoming, Reifschneider and Stevenson (1991) and Battese and Coelli (1995), among others, have proposed a one stage approach such

\footnotetext{
${ }^{3}$ SFA has also been applied to other contexts. For example, Mosheim and Knox Lovell (2009) analyse dairy farm performance; Park (2011) evaluates human resource practices in food retailing; while Obeng (2013) estimates technical efficiency for public transit systems.
} 
that the parameters for both the stochastic frontier and the determinants of inefficiency can be estimated simultaneously.

To estimate the KK model as a stochastic frontier specification, the right hand side variables are subdivided into two subsets. The first subset of gravity and skills related variables are used to identify and locate the FDI frontier, which provides an upper boundary of FDI levels against which actual FDI levels can be compared. This follows from the key assumptions of the KK model which help distinguish between the types of investment (Carr et al. 2001). First, knowledge generating activities can be geographically separated, but supplied to production facilities at low cost. Second, knowledge based activities are relatively skilled labour intensive. These assumptions create a motive for vertically integrated investment such that knowledge based activities are located where skilled labour is cheap and production is located where unskilled labour is cheap. The final assumption of the KK model motivates horizontal investment created by scale economies that allow replication of products or services in different locations.

The second subset of policy oriented variables is used as inefficiency determinants to capture the distance between actual levels of FDI and the benchmark frontier estimates. As policymakers can play a role in closing the gap between actual and maximum levels of FDI performance, appropriate policy measures can help attain the benchmark performance estimates. These policy measures include the KK policy factors (trade and investment costs) and transition related FDI policies (regional integration, infrastructure endowments and the liberalisation process). 
Following the single step maximum likelihood (ML) approach to estimating the frontier and inefficiency determinants simultaneously (Reifschneider and Stevenson 1991) using panel data (Battese and Coelli 1993; 1995), the KK specification (equation 1) is now reconfigured as a two equation model. The stochastic frontier function is defined in equation (2) and technical efficiency (TE) effects are defined in equation (3):

$$
\begin{aligned}
F D I_{i j}^{t}= & \theta_{0}+\theta_{1} G D P_{i}^{t}+\theta_{2} G D P_{j}^{t}+\theta_{3} D G D P S Q_{i j}^{t}+\theta_{4} D I S T_{i j} \\
& +\theta_{5} D_{S K I L L_{i j}^{t}}+\theta_{6}\left(D G D P_{i j}^{t} \times D S K I L L_{i j}^{t}\right) \\
& +\theta_{7}\left(T R A D E C O S T_{j}^{t} \times D S K I L L S Q_{i j}^{t}\right)+v_{i j}^{t}-u_{i j}^{t}
\end{aligned}
$$

where the error term is constructed as the sum of a symmetrically distributed random error term with zero mean and variance, $v_{i j}^{t} \sim i i d N\left(0, \sigma_{v}^{2}\right)$, and an asymmetric nonnegative technical inefficiency term, $u_{i j}^{t}$. The distribution of the latter is defined as $N\left(\delta z_{i j}^{t}, \sigma_{u}^{2}\right)$ truncated at zero where $z_{i j}^{t}$ is a vector of FDI policy factors and $\delta$ represents the corresponding set of parameters to be estimated:

$$
\begin{aligned}
& u_{i j}^{t}=\delta_{0}+\delta_{1} \text { TRADECOST }_{i}^{t}+\delta_{2} \text { TRADECOST }_{j}^{t}+\delta_{3} \text { INVCOST }_{j}^{t} \\
& +\delta_{4} E U 04_{i j}^{t}+\delta_{5} E U 07_{i j}^{t}+\delta_{6} I N F R A S_{j}^{t}+\delta_{7} L I B_{j}^{t}+w_{i j}^{t}
\end{aligned}
$$

where the variance of FDI inefficiency has a systematic component, $z_{i j}^{t} \delta$, associated with policy factors and a random component, $w_{i j}^{t} \sim N\left(0, \sigma_{w}^{2}\right)$, bounded by the truncation point $-z_{i j}^{t} \delta^{\prime}$. Note that the Reifschneider and Stevenson (1991) approach to SFA allows for a heteroscedastic relation. The FDI related policy variables comprise the cost variables of the KK model and additional policy variables that can also affect FDI efficiency. Specifically, FDI performance should be closer to frontier estimates as a consequence of all ten countries joining the EU during the 1996 to 2007 period. The development of a 
modern and efficient infrastructure is also potentially important in supporting FDI and the wider economy. During this period, infrastructure investment has been directed at improving telecommunications, energy supply and water treatment among other infrastructure projects. Furthermore, the general liberalisation of prices and reforms to trade and the foreign exchange system as well as the privatisation process is a notable feature of the transition phase from communism to market based economies.

The two EU dummies are assigned values of unity when eight of the ten new member countries gained official membership of the EU in 2004, EU $04_{i j}^{t}$, and the EU15 became the EU25, later becoming the EU27 when Bulgaria and Romania joined in 2007, $E U 07_{i j}^{t}$. The two composite indexes comprise an index of physical infrastructure, $I N F R A S_{j}^{t}$, reflecting the reform of telecommunications, railways, electric power, roads as well as water and waste water; and an index of liberalisation, $L I B_{j}^{t}$, which comprises a set of indicators related to enterprises, markets and trade as well as financial institutions. After parameterising the model, the values for technical efficiency (TE) estimates of FDI are obtained by the conditional expectation given the model assumptions, $T E_{i j}^{t}=\exp \left(-u_{i j}^{t}\right) \mid \varepsilon_{i j}^{t}$ (Battese and Coelli 1993). The point estimates of efficiency vary for each country pair due to the random error component and range in value between zero and unity (Aigner et al. 1977). Whereas an efficiency score of unity suggests actual FDI coincides with frontier estimates, an efficiency score of less than unity indicates scope to improve bilateral FDI performance. Moreover, the magnitude of the efficiency score provides an indication of the degree to which FDI levels between a pair of countries can 
be increased, given the KK framework. This forms the main advantage of adopting the SFA approach.

\section{Data}

The panel dataset is for bilateral FDI stocks from 10 western European countries (Austria, Denmark, Finland, France, Germany, Italy, the Netherlands, Norway, Switzerland and the United Kingdom) to 10 eastern European countries (Bulgaria, the Czech Republic, Estonia, Hungary, Latvia, Lithuania, Poland, Romania, Slovakia and Slovenia) over the period 1996 to 2007. In global terms, the advanced European countries account for 50 per cent of world FDI outward stocks as at 2007, rising to 55 per cent when the countries belonging to the European Free Trade Association (EFTA) are included (UNCTAD 2012). Of the selected group of western European countries, the United Kingdom and France rank joint highest, accounting for over 9 per cent of world outward FDI stocks respectively. Germany rates second (6.9\%) while the smaller countries including the Netherlands (4.9\%) and Switzerland (3.4\%) punch above their weight ahead of Italy $(2.2 \%)$.

The eastern European countries have been relatively successful in attracting FDI primarily from their western European counterparts. ${ }^{4}$ In particular, Poland, the Czech

\footnotetext{
${ }^{4}$ Data limitations (missing and zero values for FDI) restrict the sample size to 10 western and 10 eastern European countries; these countries represent the main parents and hosts of FDI into the region. In a conventional setting, missing bias is usually accounted for in one of three ways. First and most frequent, missing observations are simply discarded. Second, missing observations are treated as zeros [see, for
} 
Republic and Hungary dominate FDI volumes into the region, jointly accounting for 75 per cent of FDI volumes among the group of 10 countries (OECD 2010). The remaining share of FDI volumes is split unevenly between Romania and Slovakia (jointly accounting for one fifth) while the five smaller countries (Bulgaria, the Baltics and Slovenia) receive only about 5 per cent of FDI volumes between them. The sample period covers the transition phase from communism to EU accession, ending in 2007 before the effects of the global financial crisis have distortionary effects on FDI patterns.

The data sources are as follows. Bilateral FDI stocks, in US dollars, are from the International Direct Investment Statistics (IDIS), Organisation for Economic Cooperation and Development (OECD). In real terms, FDI stocks are deflated by US producer prices (2000 $=100)$, sourced from the International Financial Statistics (IFS), International Monetary Fund (IMF). GDP, at constant 2000 US dollars, is from the World Development Indicators (WDI), World Bank as is skilled labour, measured as the percentage ratio of enrolment in tertiary education. ${ }^{5}$ The geographic distance between capital cities, measured in kilometres, is from the CEPII.

example, Carr et al. (2001), who apply a Tobit procedure to the expanded set of observations]. Finally and more recently, the Heckman two stage selection procedure has been employed as a correction method for sample selection (Razin et al. 2004). The Tobit and Heckman procedures, however, are not compatible with SFA estimation hence the first option is used and the missing data are dropped. Moreover, to obtain a measure of FDI performance using SFA, positive values for FDI are required. At any rate, missing data for FDI stocks are much fewer than for FDI flows, accounting for just one fifth of observations in the dataset.

${ }^{5}$ To prevent loss of information, period averages substitute for missing data before 1999 and secondary school enrolment ratios substitute for missing German data. 
The economic freedom indexes are from The Heritage Foundation. ${ }^{6}$ The trade freedom index is a composite measure of the absence of tariffs and nontariff barriers (NTBs). While higher tariffs on imports directly raise the cost of trade, NTBs indirectly raise the cost of trade through a variety of restrictions relating to quantity, price, regulation, investment, customs as well as government intervention and discriminatory incentives. The investment index is a composite measure of the freedom investors have in a market which can be curtailed by rules, restrictions, expropriation, controls on foreign exchange and capital movements and bureaucracy that burden the investment process. Subtracting the economic freedom index values from 100, higher values represent higher barriers to trade and investment.

The infrastructure index, available from the European Bank for Reconstruction and Development (EBRD), is an overall index relating to the reform of telecommunications, railways, electric power, roads as well as water and waste water. Also available from the EBRD is the liberalisation index, which is a transition indicator of the progress from communism to market based regimes. The composite liberalisation index comprises a set of eight liberalisation indexes related to enterprises (large scale enterprises, small scale enterprises, enterprise restructuring), markets and trade related

\footnotetext{
${ }^{6}$ The use of index variables compiled from survey data to rank a country's degree of trade openness is not unusual in the existing empirical literature (see, for example, Brainard 1997; Carr et al. 2001; and Blonigen et al. 2003). Indeed, Edwards (1998) points out that in capturing different aspects of trade policy, a composite index can lead to efficiency gains when compared with separately introducing into an equation the various aspects of trade policy as independent variables. Using an index of distortions in international trade from the Heritage Foundation as one of nine indexes of openness in a growth model, Edwards (1998) finds no discernible differences in the results.
} 
variables (price liberalisation, trade and the foreign exchange system, competition policy), and financial institutions (banking reform and interest rate liberalisation, securities markets and nonbank financial institutions). Based on an ordinal ranking, a country that has attained the standards and performance of a typical industrialised country is assigned high numerical values of four or more whereas low values of less than one indicate very little progress from communism towards market based systems.

The summary statistics for the model variables, shown in Table 2, highlight several interesting features. First, zero, missing and negative observations characterise FDI stocks, implying an unbalanced panel. ${ }^{7}$ Moreover, the two measures of spread (the standard deviation of 2.07 about its mean value; and the range of 12.18 between the minimum and the maximum values) suggest some degree of FDI variability. In so far as the variance of FDI inefficiency is determined by policy factors, the Reifschneider and Stevenson (1991) approach to SFA performance analysis controls for this degree of FDI variability. Second, the measures of spread are particularly high for several right hand side variables most notably the host country trade and investment cost indexes. Third, a comparison of the mean values for the cost related factors suggest higher trade and investment barriers remain in place in the eastern European countries. Meanwhile, the mean values for the ordinally ranked EBRD indexes suggest the state of physical infrastructure lags behind the general process of liberalisation. Last, while GDP differences persist, the skills gap has narrowed between the two groups of countries.

\footnotetext{
${ }^{7}$ Outward FDI between the 10 western and the 10 eastern European countries over the period 1996 to 2007 is characterised by 241 missing values, 10 zero values and 7 negative values, thus reducing the potential number of FDI observations in the panel dataset from 1200 to 942.
} 


\section{[Insert Table 2 here]}

\section{Empirical Results}

\section{Knowledge capital model estimates}

Table 3 presents the results for the KK model of FDI stocks from 10 western to 10 eastern European countries over the 1996 to 2007 period. Column (1) shows the results for the pooled ordinary least squares (POLS) regression of the KK model (equation 1). Following, Coelli (1995), a test for negative skewness in the OLS residuals rejects the null hypothesis of zero skewness in the errors thereby providing evidence of technical inefficiency in the data and implying the stochastic frontier approach to estimating the KK model is appropriate. Furthermore, the $\chi^{2}$ test (Breusch and Pagan 1979; Cook and Weisberg 1983) rejects the null hypothesis that the error variances are equal, indicating the presence of heteroscedasticity. ${ }^{8}$ Caudill et al. (1995) have previously highlighted the sensitivity of the efficiency estimates to specification errors, namely heteroscedasticity. Nonconstant variances of either or both parts of the composed error term can cause potentially severe problems in the ML parameter estimates and the resulting efficiency scores.

Consequently, columns (2) to (5) present the single step ML estimates for the two equation stochastic frontier specification (Reifschneider and Stevenson 1991) of the KK

\footnotetext{
${ }^{8}$ Dropping the normality assumption from the null hypothesis does not alter this result; the F statistic is 25.68 and the $\chi^{2}$ (iid) is 25.05 .
} 
model (equations 2 and 3). In column (2) the variance of FDI inefficiency is modelled as a function of the KK cost variables while columns (3) to (5) incrementally expand the set of technical efficiency effects with additional FDI related policy variables.

[Insert Table 3 here]

In terms of the FDI location determinants, the GDP and distance coefficients are correctly signed, reasonable in magnitude and significant at the conventional level. Their respective coefficients suggest FDI rises more than proportionately with total income (the summed values for GDP is greater than unity) and falls proportionately with transaction costs (distance values are reasonably close to unity). Although the smaller GDP coefficient for the eastern European countries indicates scope to attract more FDI, the squared difference of GDP coefficient suggests the two groups of countries are sufficiently similar in size to support HFDI.

The skills related variables, however, tend to go against the predictions of the KK model of VFDI between countries of differing skilled labour endowments. Placing a strong emphasis on education and training, many excommunist countries offer a highly skilled workforce at a relatively lower labour cost. Indeed, the skills gap between the two groups of countries is sufficiently narrow so as to strongly encourage HFDI, as indicated by the negatively signed skills difference coefficient. Sufficiently similar in economic size and skilled labour endowments, the positively signed coefficient for the first interaction term runs counter to the KK model prediction that FDI abroad is highest when the home country is small and is relatively skilled labour abundant. The negatively signed coefficient for the second interaction term is consistent with the KK model prediction; 
high trade costs in the host country coupled with similar skilled labour endowments deter VFDI.

In a conventional setting of FDI location determinants, the three cost variables representing trade and investment restrictions (TRADECOST ${ }_{i}^{t}, T R A D E C O S T_{j}^{t}$ and $I N V C O S T_{j}^{t}$ ) are associated with negative, positive and negative coefficient signs respectively. As determinants of the variance of FDI inefficiency within the SFA framework (Reifschneider and Stevenson 1991), opposing coefficient signs are expected. A similar interpretation is required for the policy variables accounting for European intraregional integration, infrastructure endowments and the liberalising process from communism to market based regimes. Modelled as location determinants of FDI these policy coefficients should be positively signed, but under the SFA framework the expected negative coefficient signs should reduce the variation of FDI inefficiency. In other words, less inefficiency (more efficiency) helps close the gap between actual FDI performance and frontier estimates.

Of the cost variables, trade restrictions in the source country only is found to significantly affect FDI, whether in relation to the traditional interpretation - the POLS estimate in column (1) indicating VFDI is reduced - or the SFA interpretation in columns (2) and (3). Neither the trade nor the investment restrictions in the host country significantly affect FDI, implying other policy factors are at stake in reducing the distance from efficient frontier estimates.

For the remaining determinants of the variance of FDI inefficiency all four coefficients are negatively signed, but are not always significant. Included independently in column (3) are the EU dummies. Although the relatively higher magnitude for the 
EU07 dummy suggests the efficiency gains of regional integration have greater effect for the two newest member countries, it does not significantly affect FDI. Interestingly, the EU04 dummy loses its marginal significance in columns (3) and (4) as the effects of regional integration are picked up by the infrastructure and the liberalisation indexes. Easing congestion and transport costs, better telecommunications and an interconnected regional network of roads and railways promotes regional integration. The liberalisation process of transition also brought with it many of the benefits associated with the European single market programme, for example, the removal of trade obstacles is associated with reforms related to enterprises, markets and trade as well as financial institutions. ${ }^{9}$

Taken together, the set of policy variables significantly lower the inefficiency of FDI performance. Therefore, the full model shown in column (5) forms the preferred stochastic frontier specification of the KK model of FDI determinants into the eastern European countries. Accordingly, the efficiency scores generated from this specification form the basis of assessing FDI performance between the western and the eastern European countries.

\section{FDI efficiency scores}

Taking the FDI efficiency score for each bilateral pair of countries and averaging over the years 1996 to 2007, the results are shown in Table 4. High efficiency scores suggest direct investment between two countries is close to maximum levels of FDI whereas low

\footnotetext{
${ }^{9}$ To an extent, these effects are also picked up by the host country cost indexes, although not significantly.
} 
efficiency scores indicating deviations of actual FDI from frontier estimates suggest scope for improved FDI performance.

[Insert Table 4 here]

Highest versus lowest bilateral scores: The bilateral efficiency scores suggest a very uneven pattern of FDI performance among the new member states. Specifically, a score difference of 58 separates the best performance (an efficiency score of 76 between Hungary vis à vis Germany and the Netherlands) and the worst performance (an efficiency score of 18 between Lithuania vis à vis Austria and Bulgaria vis à vis Norway).

Highest versus lowest average scores: The range of FDI performance remains substantial when averaged across the western European countries (final column of Table 4). At the top end, Hungary achieves the highest score of 68 followed by Estonia (57) and Poland (56) while, at the other end, Lithuania, Slovakia and Slovenia attain efficiency scores ranging from 39 to 41 only. Averaging the bilateral efficiency scores instead across the eastern European countries (final row of Table 4), the range of FDI performance is more limited (from a high of 55 for Denmark to 41 for Italy), suggesting a more homogeneous pattern of outward FDI performance from the selected group of 10 western European countries.

High average scores: Of the top 3 recipients of FDI (the Czech Republic, Hungary and Poland), two are among the most efficient. Hungary performs best achieving two thirds 
of maximum levels while Estonia and Poland are placed second and third in the average rankings, attaining over half of frontier estimates. Not surprisingly, the three most efficient performers share similar rankings in the EBRD indexes with Estonia and Poland exchanging second and third places. No doubt their relatively good progress of early liberalisation and infrastructure developments helped contribute to a more efficient FDI performance. A highly skilled labour force, as measured by tertiary enrolment rates, is also shared by these three countries. In addition, Estonia's openness to trade and investment - it is by far the least restrictive in terms of investment according to the Heritage indexes - helps make it one of the most efficient FDI performers in the region.

Intermediate average scores: In so far as the two latest EU entrants (Bulgaria and Romania), the Czech Republic (an EBRD graduate) and one of the Baltic states (Latvia) attain a score of around 50, a rather heterogeneous group of countries share joint fourth in the average rankings. A diversity of country size, skills level and restrictiveness of trade and investment characterise these countries with the Czech Republic and Romania being the larger of the four countries; Latvia the more highly skilled; and Bulgaria and Romania the more costly to trade and investment. Although exhibiting good progress in the liberalisation process of transition, these countries would benefit from an improved infrastructure of telecommunications and a better network of roads and railways.

Low average scores: Trailing behind in the efficiency scores are Lithuania, Slovakia and Slovenia. A mix of country characteristics describes these countries. Slovakia is much larger in terms of GDP, more than double the size of Lithuania and about one third more 
than Slovenia; Slovakia has a relatively low skills base in contrast to the two other countries' highly educated labour force; and together with Lithuania, Slovakia is reasonably open to trade and investment in comparison to Slovenia's more restrictive environment.

\section{Conclusions}

In integrating the horizontal and vertical motives of MNE activities, the KK model relates firm types to country characteristics. The rationale for vertical investment and the incentive to geographically separate production by stages depends largely on the direct effect of skilled labour differences and indirect effects captured by interaction terms. The rationale for horizontal investment is explained in terms of the benefits of accessing large markets and attempts to avoid high trade costs via local production of similar goods in multiple countries. Specified as a general model to explain the location determinants of FDI, the KK model does not account for technical inefficiency in the data. Estimating the KK model as a stochastic frontier specification (Reifschneider and Stevenson 1991), the FDI location and variance of inefficiency determinants are quantified for a panel of FDI stocks from 10 western to 10 eastern European countries over the transition period of 1996 to 2007.

In terms of the FDI location determinants, the predictions of the KK model are largely upheld for the group of 10 eastern European countries. Specifically, the gravity factors of GDP and distance are as expected. The main exception is the skills difference coefficient; its independent effect and interaction with the GDP difference suggest skilled 
labour similarities induce HFDI to the eastern European countries in contrast to labour force differences aligned with VFDI predicted for a larger and more varied sample of countries. In terms of the variance of inefficiency determinants, source country trade costs and EU accession in 2004 are significant and marginally significant respectively, but become redundant when the full set of policy variables are added to the model. For the full model, the variance of FDI inefficiency is jointly determined by infrastructure developments and the process of liberalisation. To an extent, these index variables pick up the effects of trade and investment restrictions as well as regional integration when added to the model independently.

In identifying the efficiency of FDI performance relative to maximum potential levels for the group of ten eastern European countries, the top performers comprise Hungary, Estonia and Poland while the worst performers are Lithuania, Slovakia and Slovenia. More progress towards fully functional market economies should help improve the efficiency of FDI performance in the eastern European countries. The knowledge based economy - increasingly digital - requires a broad set of reforms. In particular, reforms to competition policy, banking and the securities markets have been relatively slow to date. Infrastructure also lags behind the standards of the industrialised countries; while good roads and railways are essential to enhancing FDI efficiency in the manufacturing sector, a reliable broadband and extensive mobile coverage become a necessity in the digital economy. Education and training are vital components of the knowledge economy as design and engineering replace the more basic skills of labour intensive manufacturing. Keeping trade and investment free remains important, hence the 
benefits of the single market programme associated with EU membership also has a role to play in improving FDI performance. 


\section{References}

Aigner, D., Knox Lovell, C. A. and Schmidt, P. (1977) Formulation and estimation of stochastic frontier production function models, Journal of Econometrics, 6, 21-37.

Alvarez, A., Amsler, C., Orea, L. and Schmidt, P. (2006) Interpreting and testing the scaling property in models where inefficiency depends on firm characteristics, Journal of Productivity Analysis, 25, 201-212.

Armstrong, S. (2011) Assessing the scale and potential of Chinese investment overseas: an econometric approach, China \& World Economy, 19, 22-37.

Battese, G. E. and Coelli, T. J. (1993) A stochastic frontier production function incorporating a model for technical inefficiency effects, Working Paper No. 69, University of New England, Armidale.

Battese, G. E. and Coelli, T. J. (1995) A model for technical inefficiency effects in a stochastic frontier production function for panel data, Empirical Economics, 20, 325-32.

Bellak, C., Leibrecht, M. and Riedl, A. (2008) Labour costs and FDI flows into central and eastern European countries: a survey of the literature and empirical evidence, Structural Change and Economic Dynamics, 19, 17-37.

Bellak, C., Leibrecht, M. and Damijan, J. P. (2009) Infrastructure endowment and corporate income taxes as determinants of foreign direct investment in central and eastern European countries, The World Economy, 32, 267-90.

Bevan, A. A. and Estrin, S. (2004) The determinants of foreign direct investment into European transition economies, Journal of Comparative Economics, 32, 775-87. 
Blonigen, B. A., Davies, R. B. and Head, K. (2003) Estimating the knowledge capital model of the multinational enterprise: comment, American Economic Review, 93, 980-94.

Brainard, S. L. (1997) An empirical assessment of the proximity-concentration trade-off between multinational sales and trade, American Economic Review, 87, 520-44.

Breusch, T. S. and Pagan, A. R. (1979) A simple test for heteroscedasticity and random coefficient variation, Econometrica, 47, 1287-94.

Carr, D. L., Markusen, J. R. and Maskus, K. E. (2001) Estimating the knowledge capital model of the multinational enterprise, American Economic Review, 91, 693-708.

Carstensen, K. and Toubal, F. (2004) Foreign direct investment in central and eastern European countries: a dynamic panel analysis, Journal of Comparative Economics, $32,3-22$.

Caudill, S. B., Ford J. M. and Gropper D. M. (1995) Frontier estimation and firm-specific inefficiency measures in the presence of heteroscedasticity, Journal of Business and Economic Statistics, 13, 105-11.

Centre d'etudes prospectives et d'informations internationales (CEPII), 2011. Available at http://www.cepii.fr/anglaisgraph/bdd/distances.htm. CEPII, Paris.

Clausing, K. A. and Dorobantu, C. L. (2005) Re-entering Europe: does European Union candidacy boost foreign direct investment?, Economics of Transition, 13, 77-103.

Coelli, T. J. (1995) Estimators and hypothesis tests for a stochastic frontier function: a Monte Carlo analysis, Journal of Productivity Analysis, 60, 247-68.

Cook, R. D. and Weisberg S. (1983) Diagnostics for heteroscedasticity in regression, Biometrika, 70, 1-10. 
Demekas, D.G., Balász, H., Ribakova, E. and Wu, Y. (2007) Foreign direct investment in European transition economies - The role of Policies, Journal of Comparative Economics, 35, 369-86.

Edwards, S. (1998) Openness, productivity and growth: What do we really know?, The Economic Journal, 108, 383-98.

Egger, P. (2010) Bilateral FDI potentials for Austria, Empirica, 37, 5-17.

European Bank for Reconstruction and Development (2011), Available at http://www.ebrd.com/pages/research/economics/data/macro.shtml. EBRD, London. International Monetary Fund (2011) International Financial Statistics (IFS), ESDS International, University of Manchester.

Kalirajan, K. (2008) Gravity model specification and estimation: Revisited, Applied Economic Letters, 15, 1037-39.

Kumbhakar, S. C. and Knox Lovell, C. A. (2000) Stochastic frontier analysis, Cambridge University Press, New York and Melbourne.

Meeusen, W. and van den Broeck, J. (1977) Efficiency estimation from Cobb-Douglas production functions with composed error, International Economic Review, 18, $435-44$.

Mosheim, R. and Knox Lovell, C. A. (2009) Scale economies and inefficiency of U.S. dairy farms, American Journal of Agricultural Economics, 91, 777-94.

Obeng, K. (2012) Bus transit technical efficiency using latent class stochastic indirect production frontier, Applied Economics, 45, 3933-42.

Organisation for Economic Co-operation and Development (2010) International Direct Investment Statistics (IDIS), ESDS International, University of Manchester. 
Park, T. A. and Davis, E. E. (2011) Productivity and efficiency impacts of human resources practices in food retailing, Applied Economics, 43, 4689-97.

Razin, A., Rubinstein, Y. and Sadka, E. (2004) Fixed costs and FDI: The conflicting effects of productivity shocks, Working Paper, No. 10864, National Bureau of Economic Research, Cambridge MA.

Reifschneider, D. and Stevenson, R. (1991) Systematic departures from the frontier: a framework for the analysis of firm inefficiency, International Economic Review, 32, 715-23.

Rojec, M. and Damijan, J. P. (2008) Relocation via foreign direct investment from old to new EU member states: scale and structural dimension of the process, Structural Change and Economic Dynamics, 19, 53- 65.

The Heritage Foundation (2012), Available at http://www.heritage.org. The Heritage Foundation, Washington.

United Nations Conference on Trade and Development (2012), Available at http://www.unctadstat.unctad.org. UNCTAD, Geneva.

World Bank (2011), World Development Indicators (WDI), ESDS International, University of Manchester. 
Table 1. Regression model variable description

\begin{tabular}{|c|c|}
\hline Variable & Description \\
\hline \multicolumn{2}{|c|}{ Location determinants } \\
\hline$F D I_{i j}^{t}$ & $\begin{array}{l}\text { The log of bilateral FDI stocks (US dollars), deflated by US } \\
\text { producer prices }(2000=100) .\end{array}$ \\
\hline$G D P_{i}^{t}$ & $\begin{array}{l}\text { The log of GDP (constant } 2000 \text { US dollars) for the source } \\
\text { country. }\end{array}$ \\
\hline$G D P_{j}^{t}$ & $\begin{array}{l}\text { The log of GDP (constant } 2000 \text { US dollars) for the host } \\
\text { country. }\end{array}$ \\
\hline$D G D P S Q_{i j}^{t}$ & $\begin{array}{l}\text { The square of the difference between the } \log \text { of the two } \\
\text { countries' GDP levels: } D G D P S Q_{i j}^{t}=\left(\ln G D P_{i}^{t}-\ln G D P_{j}^{t}\right)^{2} \text {. }\end{array}$ \\
\hline$D I S T_{i j}$ & $\begin{array}{l}\text { The log of the great circle distance }(\mathrm{km}) \text { between the capital } \\
\text { cities of two countries. }\end{array}$ \\
\hline \multirow{3}{*}{$D S K I L L_{i j}^{t}$} & $\begin{array}{l}\text { The difference between the log of the two countries' skills } \\
\text { levels, measured as the percentage ratio of enrolment in }\end{array}$ \\
\hline & tertiary education: $D S K I L L_{i j}^{t}=\left(\ln S K I L L_{i}^{t}-\ln S K I L L_{j}^{t}\right)$ \\
\hline & An interaction term between the log of the difference of \\
\hline \multirow{3}{*}{$\begin{array}{l}D G D P_{i j}^{t} \\
\quad \times D S K I L L_{i j}^{t}\end{array}$} & GDP, $D G D P_{i j}^{t}=\left(\ln G D P_{i}^{t}-\ln G D P_{j}^{t}\right)$, and the $\log$ of the \\
\hline & difference in the skills level, \\
\hline & $D S K I L L_{i j}^{t}=\left(\ln S K I L L_{i}^{t}-\ln S K I L L_{j}^{t}\right)$ \\
\hline \multirow{2}{*}{$\begin{array}{l}T R A D E C O S T_{j}^{t} \\
\quad \times D S K I L L S Q_{i j}^{t}\end{array}$} & $\begin{array}{l}\text { An interaction term between trade costs in the host country } \\
\text { and the square of the difference between the log of the two } \\
\text { countries' skills levels: }\end{array}$ \\
\hline & $D S K I L L S Q_{i j}^{t}=\left(\ln S K I L L_{i}^{t}-\ln S K I L L_{j}^{t}\right)^{2}$ \\
\hline \multicolumn{2}{|c|}{ Variance of inefficiency determinants } \\
\hline$T R A D E C O S T_{i}^{t}$ & Trade costs for the source country: $\left(100-T R A D E F R E E_{i}^{t}\right)$ \\
\hline$T R A D E C O S T_{j}^{t}$ & Trade costs for the host country: $\left(100-T R A D E F R E E_{j}^{t}\right)$ \\
\hline$I N V C O S T_{j}^{t}$ & Investment costs for the host country: $\left(100-I N V F R E E_{j}^{t}\right)$ \\
\hline$E U 04_{i j}^{t}$ & $\begin{array}{l}\text { A dummy variable equal to unity denoting EU membership } \\
\text { for eight new member states in } 2004 \text {. }\end{array}$ \\
\hline$E U 07_{i j}^{t}$ & $\begin{array}{l}\text { A dummy variable equal to unity denoting EU membership } \\
\text { for two new member states in } 2007 \text {. }\end{array}$ \\
\hline$I N F R A S_{j}^{t}$ & $\begin{array}{l}\text { A composite index related to the reform of } \\
\text { telecommunications, railways, electric power, roads and } \\
\text { water and waste water. }\end{array}$ \\
\hline$L I B_{j}^{t}$ & $\begin{array}{l}\text { A composite index related to enterprises, markets and trade } \\
\text { and financial institutions. }\end{array}$ \\
\hline
\end{tabular}


Table 2. Summary statistics

\begin{tabular}{lccccc}
\hline \hline Variable & Mean & $\begin{array}{c}\text { Standard } \\
\text { deviation }\end{array}$ & MinimumMaximum & $\begin{array}{c}\text { No. of } \\
\text { obs }\end{array}$ \\
\hline Location determinants & & & & & \\
$\quad$ FDI Stocks & 5.48 & 2.07 & -2.30 & 9.88 & 942 \\
$\quad$ Source country GDP & 26.81 & 1.02 & 25.33 & 28.36 & 1200 \\
Host country GDP & 24.00 & 0.97 & 22.19 & 26.14 & 1200 \\
GDP difference squared & 9.87 & 8.17 & $0.63 \times 10^{-4}$ & 35.91 & 1200 \\
Distance & 6.92 & 0.61 & 4.09 & 7.66 & 1200 \\
Skills difference & 0.16 & 0.44 & -0.86 & 1.45 & 1200 \\
GDP difference & 0.34 & 1.30 & -2.87 & 5.71 & 1200 \\
$\quad \times$ Skills difference & & & & & \\
Host country trade costs & 5.83 & 8.21 & $0.99 \times 10^{-5}$ & 54.92 & 1200 \\
$\quad \times$ Skills difference squared & & & & & \\
Variance of inefficiency determinants & 20.19 & 3.75 & 10.80 & 36.40 & 1200 \\
Source country trade costs & 26.04 & 9.54 & 13.40 & 53.20 & 1200 \\
Host country trade costs & 33.75 & 12.66 & 10.00 & 70.00 & 1200 \\
Host country investment costs & 0.21 & 0.41 & 0.00 & 1.00 & 1200 \\
EU-04 & 0.01 & 0.11 & 0.00 & 1.00 & 1200 \\
EU-07 & 2.87 & 0.53 & 1.00 & 3.67 & 1080 \\
Physical infrastructure & 3.49 & 0.31 & 2.46 & 4.00 & 1080 \\
Liberalisation & & & & & \\
\hline
\end{tabular}


Table 3. A stochastic frontier specification of FDI location and variance determinants ${ }^{\mathrm{a}, \mathrm{b}}$

\begin{tabular}{|c|c|c|c|c|c|c|}
\hline Regressors & (1) & $(2)$ & (3) & (4) & $(5)$ & $\begin{array}{l}\text { Expected } \\
\text { sign }\end{array}$ \\
\hline \multicolumn{7}{|l|}{ Location determinants } \\
\hline Source country GDP & $\begin{array}{c}1.17 * * \\
(0.10)\end{array}$ & $\begin{array}{c}1.24 * * \\
(0.10)\end{array}$ & $\begin{array}{c}1.19 * * \\
(0.10)\end{array}$ & $\begin{array}{c}1.21^{* *} \\
(0.11)\end{array}$ & $\begin{array}{c}1.21 * * \\
(0.10)\end{array}$ & $(+)$ \\
\hline Host country GDP & $\begin{array}{l}0.59 * * \\
(0.09)\end{array}$ & $\begin{array}{c}0.47 * * \\
(0.09)\end{array}$ & $\begin{array}{c}0.50 * * \\
(0.09)\end{array}$ & $\begin{array}{c}0.40 * * \\
(0.10)\end{array}$ & $\begin{array}{c}0.37 * * \\
(0.09)\end{array}$ & $(+)$ \\
\hline GDP difference squared & $\begin{array}{c}-0.14 * * \\
(0.02)\end{array}$ & $\begin{array}{c}-0.15^{* *} \\
(0.01)\end{array}$ & $\begin{array}{c}-0.15^{* *} \\
(0.02)\end{array}$ & $\begin{array}{c}-0.15^{* *} \\
(0.02)\end{array}$ & $\begin{array}{c}-0.15 * * \\
(0.02)\end{array}$ & $(-)$ \\
\hline Distance & $\begin{array}{l}-1.26^{* *} \\
(0.06)\end{array}$ & $\begin{array}{c}-1.18^{* *} \\
(0.06)\end{array}$ & $\begin{array}{c}-1.18 * * \\
(0.07)\end{array}$ & $\begin{array}{c}-1.13^{* *} \\
(0.10)\end{array}$ & $\begin{array}{c}-1.08 * * \\
(0.09)\end{array}$ & $(-)$ \\
\hline Source country trade costs & $\begin{array}{c}-0.07 * * \\
(0.01)\end{array}$ & - & - & - & - & $(-)$ \\
\hline Host country trade costs & $\begin{array}{c}-0.49 \times 10^{-3} \\
(0.00)\end{array}$ & - & - & - & - & $(+)$ \\
\hline Host country investment costs & $\begin{array}{c}-0.69 \times 10^{-2} \\
(0.00)\end{array}$ & - & - & - & - & $(-)$ \\
\hline Skills difference & $\begin{array}{c}-1.55^{* *} \\
(0.21)\end{array}$ & $\begin{array}{c}-1.48 * * \\
(0.19)\end{array}$ & $\begin{array}{c}-1.53 * * \\
(0.20)\end{array}$ & $\begin{array}{c}-1.77 * * \\
(0.21)\end{array}$ & $\begin{array}{c}-1.79 * * \\
(0.21)\end{array}$ & $(+)$ \\
\hline $\begin{array}{l}\text { GDP difference } \\
\times \text { Skills difference }\end{array}$ & $\begin{array}{l}0.74 * * \\
(0.07)\end{array}$ & $\begin{array}{l}0.70 * * \\
(0.07)\end{array}$ & $\begin{array}{c}0.72 * * \\
(0.07)\end{array}$ & $\begin{array}{c}0.85 * * \\
(0.07)\end{array}$ & $\begin{array}{c}0.86^{* * *} \\
(0.07)\end{array}$ & $(-)$ \\
\hline $\begin{array}{l}\text { Host country trade costs } \\
\times \text { Skills difference squared }\end{array}$ & $\begin{array}{c}-0.04 * * \\
(0.01)\end{array}$ & $\begin{array}{c}-0.04 * * \\
(0.01)\end{array}$ & $\begin{array}{c}-0.05 * * \\
(0.01)\end{array}$ & $\begin{array}{c}-0.05 * * \\
(0.01)\end{array}$ & $\begin{array}{c}-0.05 * * \\
(0.01)\end{array}$ & $(-)$ \\
\hline Intercept & $\begin{array}{c}-28.45 * * \\
(1.51)\end{array}$ & $\begin{array}{c}-28.51 * * \\
(1.40)\end{array}$ & $\begin{array}{c}-27.97 * * \\
(1.41)\end{array}$ & $\begin{array}{c}-26.51 * * \\
(1.48)\end{array}$ & $\begin{array}{c}-25.95^{* *} \\
(1.44)\end{array}$ & \\
\hline \multicolumn{7}{|c|}{ Variance of inefficiency determinants } \\
\hline Source country trade costs & - & $\begin{array}{c}0.12 * * \\
(0.02)\end{array}$ & $\begin{array}{c}0.10 * * \\
(0.02)\end{array}$ & $\begin{array}{l}0.04 \\
(0.03)\end{array}$ & $\begin{array}{l}0.04 \\
(0.03)\end{array}$ & $(+)$ \\
\hline Host country trade costs & - & $\begin{array}{l}0.01 \\
(0.01)\end{array}$ & $\begin{array}{c}-0.01 * \\
(0.01)\end{array}$ & $\begin{array}{r}-0.01 \\
(0.01)\end{array}$ & $\begin{array}{c}-0.01 \\
(0.01)\end{array}$ & $(-)$ \\
\hline Host country investment costs & - & $\begin{array}{l}0.01 \\
(0.01)\end{array}$ & $\begin{array}{l}0.01 \\
(0.01)\end{array}$ & $\begin{array}{r}-0.01 \\
(0.01)\end{array}$ & $\begin{array}{l}-0.01 \\
(0.01)\end{array}$ & $(+)$ \\
\hline EU-04 & - & - & $\begin{array}{c}-0.36^{*} \\
(0.18)\end{array}$ & $\begin{array}{l}-0.23 \\
(0.23)\end{array}$ & $\begin{array}{l}-0.02 \\
(0.22)\end{array}$ & $(-)$ \\
\hline EU-07 & - & - & $\begin{array}{c}-1.90 \\
(2.35)\end{array}$ & $\begin{array}{l}-2.20 \\
(11.61)\end{array}$ & $\begin{array}{l}-2.00 \\
(8.32)\end{array}$ & $(-)$ \\
\hline Physical infrastructure & - & - & - & $\begin{array}{c}-1.53 * * \\
(0.31)\end{array}$ & $\begin{array}{c}-1.25^{* *} \\
(0.26)\end{array}$ & $(-)$ \\
\hline Liberalisation & - & - & - & - & $\begin{array}{c}-1.42 * * \\
(0.42)\end{array}$ & $(-)$ \\
\hline No. of obs & 942 & 942 & 942 & 831 & 831 & \\
\hline$R^{2}$ & 0.73 & - & - & - & - & \\
\hline$\chi^{2 \mathrm{c}}$ & $\begin{array}{c}31.99 * * \\
(0.00)\end{array}$ & - & - & - & - & \\
\hline
\end{tabular}

Notes: ${ }^{\text {a }}$ Standard errors are reported in parentheses.

${ }^{\mathrm{b}} \mathrm{A} z$-test for negative skewness in the OLS residuals ( $\mathrm{z}$-value is $-4.92 ; p$-value is 0.00 ) confirmed the appropriateness of using the SFA approach to estimating the KK model.

c A chi-square test of equal variance (Breusch and Pagan 1979; Cook and Weisberg 1983); $p$-value in parentheses.

** denotes significance at the $5 \%$ level; * denotes significance at the $10 \%$ level. 
Table 4. Efficiency scores for the stochastic frontier specification of the KK model, 1996-2007

\begin{tabular}{ccccccccccccc}
\hline \hline & AUT & DNK & FIN & FRA & DEU & ITA & NLD & NOR & CHE & UKK & Average \\
\hline BGR & 0.54 & 0.42 & - & 0.41 & 0.48 & 0.61 & 0.56 & 0.18 & 0.54 & 0.48 & 0.47 \\
CZE & 0.56 & 0.58 & 0.40 & 0.46 & 0.51 & 0.20 & 0.64 & 0.50 & 0.52 & 0.41 & 0.48 \\
EST & 0.44 & 0.66 & 0.55 & 0.56 & 0.47 & 0.58 & 0.58 & 0.60 & - & 0.66 & 0.57 \\
HUN & 0.67 & 0.64 & 0.72 & 0.68 & 0.76 & 0.54 & 0.76 & 0.69 & 0.64 & 0.68 & 0.68 \\
LVA & 0.33 & 0.68 & 0.49 & 0.30 & 0.58 & 0.37 & 0.38 & 0.51 & - & 0.52 & 0.46 \\
LTU & 0.18 & 0.74 & 0.53 & 0.44 & 0.40 & 0.19 & 0.24 & 0.47 & - & 0.36 & 0.39 \\
POL & 0.48 & 0.65 & 0.58 & 0.59 & 0.52 & 0.57 & 0.66 & 0.48 & 0.56 & 0.47 & 0.56 \\
ROM & 0.61 & 0.34 & 0.47 & 0.56 & 0.50 & 0.46 & 0.54 & 0.61 & 0.54 & 0.36 & 0.50 \\
SVK & 0.30 & 0.41 & 0.46 & 0.37 & 0.53 & 0.23 & 0.49 & 0.58 & 0.32 & 0.22 & 0.39 \\
SVN & 0.58 & 0.41 & 0.19 & 0.61 & 0.44 & 0.32 & 0.36 & - & - & 0.34 & 0.41 \\
Average & 0.47 & 0.55 & 0.49 & 0.50 & 0.52 & 0.41 & 0.52 & 0.51 & 0.52 & 0.45 & - \\
\hline
\end{tabular}

Notes: ${ }^{a}$ The efficiency scores are derived from the KK parameter estimates shown in Table 2, column (5), for all countries except the Czech Republic. As EBRD data are no longer made available due to its graduate status from transition, the efficiency scores for the Czech Republic are derived from the KK parameter estimates in column (3). 